\title{
Aktuális nemzetközi koczkázatkezelések a veszélyesáru-szállítások során
}

\section{Current International Risk Managements in the Transport of Dangerous Goods}

\begin{abstract}
A veszélyesáru-szállítás a kockázatos tevékenységekhez tartozik. Ezt a szállítmányozott anyag mellett az is indokolja, hogy nem lehetséges pontosan, elöre meghatározni a veszélyes anyag kiszabadulásának helyszínét. A veszélyes áruk szállitásával kapcsolatos kockázatok felmérésének és kezelésének, a kárfelszámolási beavatkozásoknak kérdése a tudomány és a kutatások aktuális témái közé tartozik nemzetközi szinten is. Jelen cikk összesíti az aktuális ismereteket a kérdéskörben, egy hasonló tanulmányon alapulva, valamint javaslatokat fogalmaz meg arra, hogyan fejleszthetö a terület az ADR-jármüvek ellenörzése és felügyelete kapcsán, mik az elérhető kárfelszámolási lehetöségek baleset esetén.
\end{abstract}

Kulcsszavak: veszélyes áruk, ellenőrzés, kockázatértékelés, beavatkozás, szállitás, kárfelszámolás

The transport of dangerous goods is a risky activity. In addition to the material transported, this is also justified by the fact that it is not possible to determine the exact location of the release of the dangerous goods in advance. The issue of assessing and managing the risks associated with the transport of hazardous material and danger elimination interventions is one of the current topics of science and research at international level. This article summarises the current knowledge on the subject based on a similar study and makes suggestions on how to improve the area in terms of inspection and supervision of $A D R$ vehicles, and what the available remediation options are in the event of an accident.

Zólyomi Müszaki Egyetem, Szlovákia, habilitált egyetemi docens, e-mail: majlingova@tuzvo.sk, ORCID: https:// orcid.org/0000-0002-7450-4004

2 Nemzeti Közszolgálati Egyetem, habilitált egyetemi docens, e-mail: pantya.peter@uni-nke.hu, ORCID: https:// orcid.org/0000-0003-2732-2766 
Keywords: dangerous goods, monitoring, risk assessment, intervention, transportation, elimination of danger

\section{Bevezetés}

A belföldi és nemzetközi áruszállítás alapvetően balesetveszélyes, különösen a közúton folytatottak esetében. A veszélyes áruk szállítása esetében fennáll a tűz, a robbanás, a vegyi égési sérülések, mérgezések vagy környezeti károk veszélye is. Alapvetően a szállítást a következő alágazatokon alkalmazzák: közúti, vasúti, légi, folyami és tengeri szállítás és csővezetékes szállítás. A baleseti kockázatnak - ami egy közúti baleseten túl további veszélyeket is eredményezhet akár a lakosság széles körére is - a csökkentése érdekében szigorú szabályokat alkalmaznak a veszélyes áruk szállítására. A már bekövetekezett balesetek esetében különleges szabályok, reagáló erők és különleges szakfelszerelések, védőfelszerelések alkalmazása szükséges. A Covid-19-járvány hatással van az élet minden területére, így jelen vizsgált kérdéskörre is. Érinti mind a megelőző, kockázatcsökkentő tevékenységet és az esetleges kárfelszámolási beavatkozó tevékenységet is.

A közúti és vasúti közlekedésben bekövetkező balesetek megelőzése érdekében kidolgozták és aláirták a veszélyes áruk nemzetközi vasúti (RID) és közúti fuvarozásáról (ADR) szóló európai megállapodásokat. Az ADR-megállapodás megkötésének fő célja a veszélyes áruk biztonságos szállításának biztosítása volt. Az ADR egyes rendelkezéseit kétévente frissítik a tudományos és műszaki fejlődés szempontjából, a veszélyes anyagok és árucikkek (például robbanékonyság, gyúlékonyság, toxicitás, fertőzések kiváltásának lehetősége, radioaktivitás, maró hatás vagy környezeti szennyezés) szállítási biztonságának növelése érdekében.

A veszélyes áruk közúti szállításával kapcsolatos kockázatok minimalizálása érdekében számos megoldást dolgoztak ki, ilyenek például a kockázatértékelési eszközök, járműellenőrző rendszerek és útvonaltervezési rendszerek, amelyek a hálózat elemzésén alapulnak. A már bekövetkezett balesetek esetében különböző reagáló szervezetek lépnek közbe, jellemzően, nemzetközi viszonylatban a tűzoltóság az elsődleges beavatkozó. A megelőző és a beavatkozó megoldások közül mutatunk be néhányat ebben a cikkben, felhasználva a szerzők idegen nyelven megjelent korábbi írását, ${ }^{3}$ mindezt aktualizálva, magyar nyelven, kibővítve a kárfelszámolási kérdések tárgyalásával is.

\section{A veszélyes áruk szállításával kapcsolatos kockázatok}

A közlekedés fontos szerepet játszik a nemzetgazdaságokban, és hatással van a gazdasági fejlödésre. Az emberre és a környezetre is veszélyes áruszállítás napjainkban igen gyakori. A Covid-19-járványhelyzet következtében világszinten és így európai szinten is változó mérték-

Andrea Majlingova - Pántya Péter: Management of risks associated with dangerous goods transportation - review. Védelem Tudomány, Katasztrófavédelmi Online Tudományos Folyóirat, 4. (2019), ksz. 220-246. 
ben és időtartamban mérséklődtek a szállítmányozások, azonban a trend továbbra is elég magas ahhoz, hogy vizsgáljuk a jelenlegi, címben felvetett kérdéskört. Összességében a közlekedés veszélyes a környezetre és az úthasználókra, megnövekedett szennyezőanyag-kibocsátást, baleseteket okoz. Az olyan alapvető termékek, mint például a benzin és a dízel iránti kereslet pandémia előtti növekedése is a veszélyes áruk szállításának növekedéséhez vezetett, ami megnövelte a közúti balesetek kockázatát.

Áttekintve és elemezve a kapcsolódó irodalmat, Adamec és munkatársai az áruk és kellékek szállítását a müködő városi infrastruktúra fenntartásának elengedhetetlen részének tekintik. ${ }^{4}$ Ez a fajta szállítás különösen a városi területeken jelenthet magas kockázatot, amely jelentősen károsíthatja a város kritikus infrastruktúráját, ha baleset történik, és veszélyes vegyi anyagok szivárognak ki. A cél ezért a kockázat és annak következményeinek minimalizálása. A hatékony eszközök e kockázatok azonosításán, elemzésén és értékelésén, a városokban található kritikus területek felkutatásán, valamint a megelőzési és biztonsági intézkedések alkalmazásának biztosításán keresztül valósulnak meg.

Kátai-Urbán és Vass áttekintette és bemutatta a veszélyesáru-szállítás felügyeletének hazai, Magyarországot érintő fejlődését az elmúlt időszakokban. ${ }^{5}$ Részletesen ismertetik a jelenlegi ellenőrzési metódusokat és eljáró hatósági szervezeteket, ezek jogszabályi alapjait.

Nowacki és társai ${ }^{6}$ az Európai Unióban és azon belül a Lengyel Köztársaságban (Lengyelországban) megvalósuló szállítási tevékenységekben a veszélyes áruk fenyegetettségének értékelésére összpontosított. Megállapításaik szerint kijelentették, hogy az Európai Unióban a veszélyes árukat jellemzően belvízi utakon, vasúton és közúton szállítják. Lengyelországban 2014-ben a veszélyes áruk 87,5\%-át közúton, 12,5\%-át vasúton szállították. Lengyelországban nincs olyan felügyeleti rendszer, amely valós időben ellenőrizné a veszélyes áruk közúti szállítását, javasolták ezért a veszélyes áruk megfigyelésének nemzeti rendszerét kialakítani. Rámutattak, hogy egy ilyen rendszer megvalósítása jelentősen hozzájárul az emberek és a környezet biztonságának javításához. 2009-ben Portugáliában a veszélyes áruk közúti szállítása a teljes áruszállítás 10\%-a volt, ami évente 10 millió tonnának felel meg. Ezen áruk körülbelül $70 \%$-a volt tüzveszélyes.

Łukasik kidolgozott és bevezetett egy kutatási módszert, amely elemezte a veszélyes áruk közúti szállításának ellenőrzési arányait az Európai Unióban és a kapcsolódó lengyel jogi dokumentumokat. ${ }^{7}$ A veszélyes áruk szállítása során bekövetkezett balesetek megelőzése érdekében meghatározták a veszélyes áruk közúti szállításának megszervezésére vonatkozó szabályokat és műszaki feltételeket, különös tekintettel az információk továbbítására és a katasztrófavédelmi, tűzoltósági szolgálatokkal való együttműködésre, valamint a mentési és kárfelszámolási

4 Vladimír Adamec-Barbora Schullerova - Vojtěch Adam: Issues of Hazardous Materials Transport and Possibilities of Safety Measures in the Concept of Smart Cities. In Smart City $360^{\circ}$. First EAI International Summit, Smart City $360^{\circ}$, Bratislava, Slovakia and Toronto, Canada, 2016. 790-799.

5 Kátai-Urbán Lajos - Vass Gyula: Veszélyes üzemek és szállítmányok biztonsága Magyarországon. Védelem Tudomány, Katasztrófavédelmi Online Tudományos Folyóirat, 4. (2019), 1. 45-82.

$6 \quad$ G. Nowacki-C. Krysiuk - R. Kopczewski: Dangerous Goods Transport Problems in the European Union and Poland. Transnav-International Journal on Marine Navigation and Safety of Sea Transportation, 10. (2016), 1. 143-150.

7 Zbigniew Łukasik - Aldona Kuśmińska-Fijałkowska - Jacek Kozyra: Transport of dangerous goods by road from a European aspect. Scientific Journal of Silesian University of Technology. Series Transport, 95. (2017), 109-119. 
műveletekre való készségükre. Kinzhikeyev és Restás írásukban a szállítmányozást érintő balesetek során történő beavatkozások segítését tekintette át. ${ }^{8}$ Javaslatukban pilóta nélküli légi járművekkel, drónokkal a tűzoltói, kárfelszámolási beavatkozások segíthetőek. Zwęgliński maradva ugyanezen a területen, ${ }^{9}$ a kárterületek drón általi légi felderítésében a jelen informatikai lehetőségekre mutatott rá, miszerint a nagy felbontású, magas nézőpontú képfelvételek és a geoinformációs adatok felhasználása és feldolgozása jelentősen segíti a beavatkozások mielőbbi, minél kisebb kockázatú végrehajtását.

Smal és munkatársai a jogi és műszaki feltételekkel, valamint a járművek jelölésével kapcsolatos kérdéseket mutatták be a választott példákon. ${ }^{10}$

\section{Kockázatvizsgálati eszközök}

A kockázatértékelés kérdése a kockázatkezelési folyamat fontos szakasza. A hatékony megelőző intézkedések megtervezéséhez és megtételéhez fontos, hogy ismerjük a balesetekre leginkább valószínűsíthető helyzeteket. Ezek sebezhetőségének és a baleset lehetséges következményeinek ismeretéhez előzetesen meg kell tervezni és biztosítani az elérhető forrásokat, erőforrásokat, hogy minimalizáljuk a baleset következményeit. Az esetlegesen bekövetkező balesetek esetén redukált mértékű veszélyesanyag-kiszabadulás esetén könnyebben kezelhető a káreset a beavatkozó erők, a tűzoltó erők számára. Számos kockázatértékelési eszközt vezettek be, amelyeket a veszélyes áruk külföldre szállítása kockázatának minimalizálása érdekében hajtottak végre.

Caliendo és De Guglielmo kvantitatív kockázatelemzést vezetett be a közúti alagutakon keresztül közlekedő veszélyes teherjárművekre vonatkozóan. ${ }^{11}$ Az óránkénti csúcsforgalmat, a nehéz tehergépjárművek százalékos arányát és a vészszellőztető rendszer meghibásodását vizsgálták annak érdekében, hogy felmérjék ezek hatását a kockázati szintre. Kiértékelték azt a kockázatot is, amely egy olyan alternatív útvonalhoz kapcsolódik, amely teljes egészében a szabadban halad, és sürün lakott városi területen halad át. Megállapították, hogy két tűz esetén is (robbanás nélkül) nagyobb a kockázat az alagútban. Ezzel szemben megnő a veszélynek kitett lakosság kockázati szintje az alternatív útvonalnál, ezért óvatosnak kell lennünk, mielőtt kijelentjük, hogy a veszélyes áruk szállítására egy teljesen szabadban futó útvonal használható, amennyiben lakott területen halad át. A kvantitatív kockázatelemzés segítheti a döntéshozókat mind a további biztonsági intézkedések végrehajtásában, mind annak megértésében, hogy engedélyezik-e, tiltják-e vagy korlátozzák-e a veszélyes árukat szállító teherjárművek forgalmát.

8 Sergey Kinzhikeyev - Ágoston Restás: Drone appliccations for supporting the disaster strategic response management the transport system. In: Karakoc Hikmet - Jozsef Rohacs - Turan Onder - Sogut M.Ziya: Abstract Book of International Symposium on Sustainable Aviation 2019 (ISSA-2019). 2019. 29.

9 Tomasz Zwęgliński: The Use of Drones in Disaster Aerial Needs Reconnaissance and Damage Assessment. Three-Dimensional Modeling and Orthophoto Map Study. Sustainability, 12. (2020), 15. 6080.

10 T. Smal - M. Kopczewski: Transportation of Dangerous Goods - Legal and Technical Conditions and Marking of Vehicles. Proceedings of the $20^{\text {th }}$ International Scientific Conference Transport Means 2016. Juodkrante, Lithuania, Oct 05-07, 2016. 191-196.

11 Ciro Caliendo - Maria Luisa De Guglielmo: Quantitative Risk Analysis on the Transport of Dangerous Goods Through a Bi-Directional Road Tunnel. Risk Analysis, 37. (2017), 1. 116-129. 
Forigua és Lyons egy esettanulmány eredményeit mutatta be Kolumbiában. ${ }^{12}$ Rámutattak arra a tényre, hogy az elmúlt években Kolumbia városaiban nőtt az áruszállítás baleseti aránya. A veszélyes áruk szállításával kapcsolatos kockázat és annak a szállítási láncra gyakorolt hatása a vállalatok vagy a nemzeti hatóságok számára nem ismert. A települési önkormányzatoknak nincs külön szabályozásuk ezen anyagok városi területeken történő szállítására, és az Infrastrukturális és Közlekedési Minisztérium irányítja az ilyen típusú árufuvarozást az országos közúti hálózatban, ideértve a városi területeken átvezető utakat is. Kutatásaik fő célja egy olyan módszertan kidolgozása volt, amely a legfontosabb változók azonosítására összpontosít, amelyek lehetővé teszik számunkra, hogy stratégiai és operatív mutatókat javasoljunk a közúti biztonság integrálására a fö veszélyes termékek Kolumbiában közúton szállított szállítási láncába. A módszertan felmérte, hogy a közlekedési lánc mely érintettjei vannak a közúti biztonság körében a stratégiai és operatív tervezés során, valamint azt is, hogy a kolumbiai városi területeken a veszélyes áruk szállításában érdekelt megrendelők, fuvarozók és járművezetők betartják-e a jogszabályoknak való megfelelést. A kutatás célja, hogy hozzájáruljon a közúti közlekedésbiztonságnak a szállítási lánc stratégiai és operatív tervezésébe történő integrálásához és az állami szintű szakpolitikák végrehajtásához szükséges elemzéshez a veszélyes áruk kolumbiai városokban történő szállítási láncának javítása érdekében, valamint magának a közlekedés hatékonyságának javításához konkrét mutatókkal, az érintett szervezetek által.

Kanj és Flaus általános megközelítést írtak le az ágensalapú modellezésről az autonóm és kölcsönhatásban lévő ágensekből álló rendszerek modellezésére a kockázatelemzéshez. ${ }^{13}$ Újfajta általános modellt mutatnak be a kockázatelemzés és a hibafa terjedésének egy ágensmodellben való bemutatására, ahol a cél egy rendszerrel kapcsolatos kockázat elemzése és viselkedésének szimulálása több módban, több ágenses rendszerek használatával. Ezt a megközelítést alkalmazzák a veszélyes áruk szállításával kapcsolatos kockázatok elemzésére és e kockázatok minimalizálására egy modell alkalmazásával (meghatározva azt a legjobb utat, amely rendelkezik a szállítás legkisebb kockázati szintjével).

Karim és szerzőtársai (2017) újabb modellt javasoltak ${ }^{14}$ a veszélyes anyagok szállítási útvonalait érintő kockázati kitettségek kiszámításához a Gauss-féle sztochasztikus szállítási idő felhasználásával. A veszélyes anyagok szállítási útvonalainak metamodelljét kibővítették a kockázatkezelési dimenzió figyelembevétele érdekében. A javasolt analitikai megoldást egy infrastruktúrába telepítették intelligens közlekedési rendszerek architektúráját felhasználva.

Krejci és mtsai. kockázatértékelési megközelítést vezetett be az ammónia és a klór lakott területen keresztül történő szállításával kapcsolatban. ${ }^{15}$ Tanulmányukban matematikai és szimulációs megközelítést hasonlítottak össze ezen anyagok közúti balesetek általi szivárgásának modelljével. Mindkét megközelítés szinergikus alkalmazása bizonyult

12 Julio Forigua - Liliana Lyons: Safety analysis of transportation chain for dangerous goods: A case study in Colombia. Transportation Research Procedia, 12. (2016), 842-850.

13 Hassan Kanj - Jean-Marie Flaus: An Agent-based framework for mitigating hazardous materials transport risk IEEE Conference on Evolving and Adaptive Intelligence Systems. Dec 01-03, France, 2015.

14 Lamia Karim et alii: Deploying Real Time Big Data Analytics in Cloud Ecosystem for Hazmat Stochastic Risk Trajectories. Procedia Computer Science, 109. (2017), 180-187.

15 L. Krejci - B. Schullerova - V. Adamec: Risk Assessment of the Transport of Ammonia and Chlorine in Urban Areas. Chemicke Listy, 112. (2018), 4. 232-236. 
a legmegfelelőbbnek - a matematikai módszer a megelőző és a mérséklő intézkedések értékelésére, míg a szimuláció az érintett terület kiterjedésének meghatározására. A veszélyes áruk szállításával járó kockázat csökkentése érdekében javasoltak meghozandó intézkedéseket.

Landucci és munkatársai bemutatták a veszélyesáru-szállítási kockázatértékelését a Viareggio PB-gáz balesetének felülvizsgálata formájában. ${ }^{16}$ Vizsgálatuk a veszélyes anyagok szállítása során felmerülő kockázatok elemzéséhez rendelkezésre álló referenciaeljárások és eszközök elemzésére irányult. Az Olaszországban 2009-ben bekövetkezett balesetet a veszélyes anyagok szállításával kapcsolatos kockázatelemzés jelenlegi megközelítésének szemszögéböl elemezték.

Az elmúlt években a veszélyes anyagok közúti fuvarozásában súlyos közlekedési balesetek fordultak elő. Ezek mind a veszélyes áruk elvesztése, mind a jármű sérülése miatt jelentős anyagi kárt okoztak a vállalkozásoknak, ugyanakkor fenyegetést jelentettek az érintett emberek számára is azon a helyen, ahol a baleset történt és annak környezetében is.

Li és Wang tanulmányukban ${ }^{17}$ először a megelőző három év 61 közúti baleseti esetének adatait gyűjtötték össze, és öt szempontból azonosították azokat a tényezőket, amelyek befolyásolják a veszélyes vegyi anyagok közúti szállításának kockázatkezelését: ember, gép, anyag, módszer és a környezet. Ezek alapján végeztek kockázatértékelést és készítettek kockázati mátrixot, javaslatot a kockázatkezeléssel kapcsolatban a vállalkozások egyszerü, könnyen érthető és hatékony kockázatkezelési rendszerének létrehozása érdekében.

Janno és Koppel rámutattak arra a tényre, ${ }^{18}$ hogy amikor a csomagolt veszélyes árukat közúton szállítják, kritikus fontosságú minden törvényi előírás betartása, valamint a javasolt biztonsági előírások betartása annak érdekében, hogy megelőzzék az emberre káros vegyi anyagokkal végzett tevékenységek során bekövetkező baleseteket, az eszközök és a környezet szennyeződését. Annak a ténynek köszönhetően, hogy a kezelési és szállítási eljárásokban több fél is részt vesz, rengeteg különböző kockázat léphet fel veszélyes árukkal végzett tevékenységek során. Cikkükben arra összpontosítottak, hogy egy veszélyes áru szállítási láncán belül különféle kockázatokat elemezzenek egy adott résztvevővel kapcsolatban. A kockázatok elemzésével és rangsorolásával a legkritikusabbakat azonosítják és értékelik a teljes láncra gyakorolt lehetséges károk alapján. Bemutattak egy elméleti szempontokon alapuló kombinált áttekintő tanulmányt, amelyet a veszélyesáru-szállítás gyakorlati kockázatértékelésére vonatkozó korábbi tanulmányok eredményei támasztanak alá. További kutatási eredmények ismertetése történik arról, hogy egy észtországi példában a felek hogyan értékelik a veszélyes áruk kezelése és szállítása során a tevékenységükből eredő lehetséges károkat. Megerősítik azt a fő megállapítást, hogy az emberi tényező az egyik kulcsfontosságú tényező a balesetek bekövetkeztében. A korlátozott vizsgálati csoport ellenére a kutatási eredmények általánosításai széles körben alkalmazhatók Európában a kockázatok univerzális jellemzői, valamint a közös

16 Gabriele Landucci et alii: HazMat transportation risk assessment: A revisitation in the perspective of the Viareggio LPG accident. Journal of Loss Prevention in the Process Industries, 49. (2017), 36-46.

17 He-Hua Li - Yu-Jie Wang: Research on the Road Transport Risk of Domestic Hazardous Chemicals. AEBMR - Advances in Economics Business and Management Research, 50. (2017), 164-171.

18 Jelizaveta Janno - Ott Koppel: Human factor as the main operational risk in dangerous goods transportation chain. Proceedings of $17^{\text {th }}$ International Scientific Conference Business Logistics in Modern Management. Osijek, Croatia Oct 12-13. 2017. 63-78. 
jogi követelmények miatt. A további kutatások körében a jelen tanulmány eredményei mérföldkövek a veszélyes áruk közúti szállításában, az emberi tényező által érintett kockázatok kezelésére összpontosítva. Az Európai Bizottság veszélyesáru-szállításra vonatkozó statisztikái szerint a balesetek akár $80 \%$-át emberi hiba, $8 \%$-át műszaki meghibásodás okozza. A munkabiztonságot és jelen kérdéskörben is a már kialakított ez irányú kultúrát vizsgálták Gabryelewicz és munkatársai. ${ }^{19}$ Mindehhez egy online kérdőívet is felhasználtak, és ez alapján egyértelmü lehet a kapcsolat a hosszú idő alatt kialakított szervezeti biztonsági kultúra és az egyes emberi tényezők általi balesetek csökkentése, elkerülése között.

Janno és Koppel operatív kockázatokat írtak le a közúti veszélyes áruk szállítási láncában. ${ }^{20}$ A szerző kijelentette, hogy mivel a kezelési és szállítási eljárásokban több fél is részt vesz, rengeteg különféle kockázat léphet fel e tevékenységek során veszélyes árukkal. Tanulmányukban a veszélyes áruk szállítási láncában az adott résztvevőhöz kapcsolódó működési kockázatok azonosítására és elemzésére összpontosítottak. A kockázatok azonosításával és értékelésével a legkritikusabbakat azonosítják és értékelik a teljes láncra gyakorolt lehetséges károk alapján. Írásuk elméleti szempontokon alapuló kombinált áttekintő tanulmányt mutat be, amelyet a veszélyesáru-szállítás gyakorlati kockázatértékelésére vonatkozó korábbi tanulmányok eredményei is alátámasztanak. Félkvantitatív kockázatértékelési módszer alkalmazásával végül lehetővé teszi a közutakon végzett veszélyesáru-szállítást érintő működési kockázatok szintjük szerinti megkülönböztetését elfogadható, elviselhető és elfogadhatatlan müködési kockázatokká.

Rada és munkatársai ismertették ${ }^{21}$ a Varese kerület (Észak-Olaszország nagyon magas népsürűségű és ipari tevékenységekkel rendelkező területe) biztonsági állapotát azzal a céllal, hogy összehasonlítsák a jelenlegi állapotot, figyelembe véve az elsődlegesen veszélyes anyagok szállítása miatti kockázatokat (autópályák és főutak) egy lehetséges forgatókönyvvel, amely néhány módosítást vezet be, például részleges áttérést a közúti árufuvarozásról a vasúti közlekedésre.

Rázga és szerzőtársai a közúti alagutak biztonságával foglalkoztak. ${ }^{22}$ Nagyon fontosnak tartották az alagutak biztonságos üzemeltetését, mert az alagutak sajátos műszaki építmények, amelyeket a közlekedési útvonalak lerövidítése és a közúti biztonság javítása érdekében építenek. 2015-ben vezették be először a közúti alagutak kockázatelemzési modelljének kiterjesztését. Ugyanezen szerzők kiszámolták ${ }^{23}$ a közúti alagutak kockázatelemzését, megépítettek egy „Alagútforgalom és üzemeltetés szimulátort”, és azon dolgoztak, hogy a kockázatelemzési modellt hozzáadják a veszélyes áruk közúti alagutakon történő szállításának kockázatelemzéséhez. A modell megvizsgálja az alagút használóinak személyes érintettségű kockázatát,

19 Izabela Gabryelewicz - Patryk Krupa - Joanna Sadłowska-Wrzesińska: Online measurement of work safety culture - statement of research. In $4^{\text {th }}$ International Conference On Computing And Solutions In Manufacturing Engineering 2016 (COSME'16), Volume 94, 2017.

20 Jelizaveta Janno - Ott Koppel: Operational risks in dangerous goods transportation chain on roads. Logforum, 14. (2018), 1. 33-41.

21 Elena Cristina Rada - Navarro Ferronato Vincenzo Torretta: Individual risk evaluation and interventions for mitigation in the transportation of hazardous goods: a case study. MATEC Web of Conferences, 121. (2017), 06008

22 Martin Rázga - E. Jančaříková - Peter Danišovič: Research of selected factors of safety in road tunnels for practice. $2^{\text {nd }}$ International Conference on Engineering Sciences and Technologies (ESaT). Slovakia, Jun 29-Jul 01. 2017.

23 Martin Rázga - Peter Danišovič - Pavel Poledňák: Extension of risk analysis model for road tunnels. Procedia Engineering, 111. (2015), 687-693. 
és statisztikailag értékeli az áldozatok várható számát évente. Úgy ítélték meg, hogy a Zsolna Egyetem (Szlovákia) alagútforgalmi és üzemeltetési szimulátora, egyedi szoftverrel kombinálva, elősegíti a normál működés során bekövetkező lehetséges működési körülmények kutatását és a káresetek modelljét.

Adamec és munkatársai ismertették a veszélyes anyagok városokban történő szállításával kapcsolatos kockázatok kérdését, ${ }^{24}$ és javaslatot tettek az intelligens városok koncepciójának kidolgozása érdekében, hogy ez hozzájáruljon a funkcionális kommunikációs hálózat kialakításához, a forgalom áramlásához a városokban, emellett elérhető a kritikus infrastruktúra biztonságának növelése.

\section{Veszélyes árut szállító járművek felügyelete}

Amikor a veszélyes áruk mozgásáról beszélünk, a nyomon követhetőség és az ellenőrzés nem csak intelligens és hatékony logisztika kérdése. Ezek a biztonsággal kapcsolatos szempontokat is magukban foglalják, mivel az érintett iparágak és hatóságok számára közös gondot jelentenek. A veszélyes áruk szállítmányának nyomon követése hatékony, időszerü és pontos információk gyüjtését igényli a különböző lépésekről, szállításokról. A megbízhatóság alapvető követelmény, különösen az intermodális szállítás esetében, ahol különböző szállítmányozók, feladók és módozatok vannak jelen. Ebben a tekintetben a müholdas navigációs technológia kulcsfontosságú elem, mivel lehetővé teszi az áruforgalom folyamatos lokalizálását, ellenőrzését és nyomon követését, illetve az adatgyűjtést a szállítás során.

A müholdas helymeghatározás használatán alapuló rendszereket napjainkban széles körben alkalmazzák a veszélyes áruk szállítási műveleteiben is. A nyomkövető eszközökbe (amelyek az árut szállító eszközre, jármüre vannak telepítve) integrálhatnak érzékelőket is, amelyek lehetővé teszik az áruk állapotának és a különböző telekommunikációs eszközök (műholdas és/ vagy földi) állapotának vagy adatátvitelének nyomon követését.

Különböző korábbi és folyamatban lévő európai kezdeményezések bevezetik az európai mủholdas navigáció használatát is, gondolva itt az EGNOS-ra ${ }^{25}$ és a Galileóra. E kezdeményezések közül a 2011-ben lezárult SCUTUM ${ }^{26}$ projekt kimerítően és sikeresen bizonyította, hogy az EGNOS pontos és megbízható lokalizációt és nyomon követést biztosít, és így különösen alkalmas a veszélyes áruk szállításának nyomon követésére. Ma a SCUTUM jóvoltából az EGNOS-t mintegy 1200 veszélyes árut közúton szállító közúti tartálykocsi megfigyelésére használják Európában (Olaszország, Franciaország, Ausztria, Szlovákia, Magyarország, Románia, Csehország). Kihasználva a SCUTUM eredményeit, a 2014-ben indult és négyéves időtartamú folyamatban lévő CORE ${ }^{27}$ projekt kiterjeszti a helymeghatározó rendszer használatát a veszélyes áruk intermodális szállítására, és elemzi a Galileo bevezetésének előnyeit. Amint azt a SCUTUM

\footnotetext{
Adamec et alii (2016) i. m.

European Geostationary Navigation Overlay Service, Európai helymeghatározó és navigációs rendszer.

26 SeCUring the EU GNSS adopTion in the dangeroUs Material transport, veszélyesáru-szállítás biztosítása Európában a GNSS által.

27 Consistently Optimized Resilient Secure Global Supply Chains, Optimalizált, biztonságos és globális ellátási lánc.
} 
tette, a CORE várhatóan egy müködés közben bevált gyakorlatot is bevezet Európában. A projekt eredményei felhasználhatók a telemetria veszélyes áruk szállításához való felhasználásával kapcsolatosan. ${ }^{28}$

Ma egyre nagyobb figyelmet fordítanak a gépjárművekre telepített felügyeleti rendszerekre annak érd ekében, hogy veszélyhelyzetekben hatékony és értékes segítséget nyújtsanak, javítva így a közlekedés biztonságát. A vizuális segédeszközök fő korlátja, hogy rossz időjárási viszonyok (például köd, eső, füst) jelenléte esetén nem adnak pontos eredményeket. Ezt a korlátot radarérzékelők segítségével is le lehet küzdeni.

Li és Gu ismertették az IC-kártya bevezetését a közúti szállításra a haszongépjárművek felügyeletében. ${ }^{29}$ Ez az IC-kártya a közúti szállításhoz tartalmazza a használó haszongépjármü tanúsítványát és kezelőjének képesítési bizonyítványát. Kínában e kártya feltétele a közúti szállításnak, amely egy elektronikus személyi igazolvány, ezt minden haszongépjárműnek és érintett szakembernek magánál kell tartania. A szerzők cikkükben röviden bemutatták ennek a Kínában alkalmazott IC-kártyának az alapvető kialakítását, adatformátumát és biztonsági kulcsainak felépítését. A haszongépjárművek felügyeletének további biztosítása érdekében javasolták a közúti fuvarozásra szolgáló IC-kártya további alkalmazási keretét. Megvitatták a kártya alkalmazási példáit az utasszállítás felügyeletében, a veszélyes áruk szállításának kezelésében, az irányítási-logisztikai kezelésében is. A gyakorlati alkalmazási eredmények azt mutatták, hogy az IC-kártya alkalmazása fontos technikai eszköz a közúti szállítási ágazatban a felügyeleti képesség javításához.

Malekian és szerzőtársai egy rádiófrekvenciás azonosítás (RFID) használatára képes intelligens jármünavigációs rendszer bevezetésével foglalkoztak a navigációs útvonalakra vonatkozó információk alapján. ${ }^{30} \mathrm{Az}$ útvonalak előrejelzéséhez és a navigációs útvonalak előzetes pontos meghatározásához prediktív algoritmusokat használtak. A rendszer lényege egy meglévő, helyben programozható táblázat és hardver a navigációs adatok gyűjtésére. Kommunikációs protokollt és adatbázist terveztek a vezető szokási adatainak tárolására is. A kapott eredmények alapján a rendszer alkalmazása során pontosan és következetesen eléri a navigációs elörejelzést, ezenkívül a soför szokásainak változását is sikeresen szürték és kimutatták.

Xie és munkatársai bemutatták a globális helymeghatározó rendszeren alapuló veszélyesáruszállítási megfigyelő rendszerüket. ${ }^{31}$ Ez egy valós idejű rendszer, amely a globális helymeghatározó rendszer, a BeiDou navigációs müholdas rendszer (BDS) és az RS485 csatlakozó felületen, buszon alapuló érzékelőmodulok segítségével folyamatosan figyelemmel kísérheti a szállítmányozott veszélyes áruk állapotát. A fenti technikai keret kombinációjában a rádióátvitel (General Packet Radio Service, GPRS), a rádiófrekvenciás azonosítás (RFID) és a földrajzi információs

28 A. Di Fazio et alii: European pathways to introduce EGNOS and Galileo for dangerous goods transport. Transportation Research Procedia, 14. (2016), 1482-1491.

29 Weiwei Li - Jingyan Gu: Application of IC Card License for Road Transportation in Commercial Vehicles Supervision and Service. MATEC Web of Conferences, 81. (2016), 03001.

30 Reza Malekian et alii: Smart Vehicle Navigation System Using Hidden Markov Model and RFID Technology. Wireless Personal Communications, 90. (2016), 4. 1717-1742.

31 Yaoyao Xie et alii: A Hazmat Transportation Monitoring System Based on Global Positioning System/ BeiDou Navigation Satellite System and RS485 bus. Proceedings of the $9^{\text {th }}$ International Congress on Image and Signal Processing, BioMedical Engineering and Informatics (CISP-BMEI). Datong, Peoples R China, Oct 15-17. 2016. 1059-1063. 
rendszer (GIS) technológiájával lehetővé teszi a rendszer számára a helyadatok figyelemmel kísérését és a veszélyes áruk alapvető állapotinformációinak biztosítását a szállítás során.

A csak GPS-technológián alapuló jármű-helymeghatározó eszközök fontos szerepet játszottak a területen, azonban vannak nyilvánvaló hiányosságok egy egyszerű GPS-módszer alkalmazásával a helymeghatározási pontosság és lefedettség szempontjából. A GPS vak, nem követett (például alagút) területén a jármű útvonala nem figyelhető meg valós időben, amit Ye és szerzőtársai vizsgáltak. ${ }^{32}$

\section{5. Útvonaltervezési eszközök}

A közúti közlekedés biztonságának javítása az egyik legfontosabb cél a közlekedéspolitikai döntéshozók számára a mai társadalomban, és szintén fontos kérdés az életminőség javítása érdekében. A közelmúltban az ISO 39001 (közúti közlekedésbiztonsági irányítás) a minőségirányítási rendszerekkel egyetértésben bevezette a közúti balesetek csökkentését célzó biztonsági alapú tevékenységek irányelveit. Ezek az irányelvek a közúthálózat-müködtetők, a használatban részt vevő üzemeltetők, érdekeltek és a magánvállalkozások számára készültek, és meghatározzák a közúti kockázat csökkentésének szabványos irányítását. Ebben az összefüggésben a veszélyes áruk szállításának kockázata különösen nagy veszélyt jelent. Számos döntéshozatali megoldást határoztak meg a közlekedési vezetők és a közigazgatás számára, de két nyitott kérdés még mindig létezik. Először is, nem léteznek olyan alkalmazások, amelyek a veszélyes áruk szállítóit támogatnák a taktikai és operatív tervezés során. A második pont a forgalmi torlódásoknak a közúti balesetek gyakoriságára gyakorolt hatásaival kapcsolatos, ezeknek a kapcsolatoknak a tanulmányozására és értékelésére nincs közös megközelítés.

A veszélyesáru-szállítási kockázatok problémája megoldásának egyik hatékony módja a veszélyesáru-szállítási útvonalak, valamint a pihenőhelyek megtervezése. Ezt a kérdést több szerző is vizsgálta. Caro-Vela és munkatársai egy hatékony algoritmus megtervezését javasolják ${ }^{33}$ a veszélyes áruk parkolóhelyeinek optimális megközelítésének meghatározásához Európában. Tanulmányukban azzal a problémával foglalkoztak, hogy a veszélyes áruk számára szükséges minimális számú parkolóhelyet megtalálják az európai közlekedési hálózatban. A probléma optimális megoldásának elérése érdekében bevezették egy új grafikonon alapuló algoritmus kialakítását, amely a parkolóhelyeket úgy helyezi el, hogy a járművezetők betarthassák a vezetési és pihenési időkre vonatkozó előírásokat.

Conca és szerzőtársai elemezték a közúti forgalom napi folyamata és a balesetek gyakorisága közötti kölcsönhatásokat. ${ }^{34}$ Integrált megközelítést javasoltak az útválasztási problémák

32 Ning Ye et alii: A hidden Markov model combined with RFID-based sensors for accurate vehicle route prediction. International Journal of Ad Hoc and Ubiquitous Computing, 23. (2016), 1-2. 124-133.

33 Maria D. Caro-Vela - Eugenio M. Fedriani - Ángel F. Tenorio: Design of an Efficient Algorithm to Determine a Near-Optimal Location of Parking Areas for Dangerous Goods in the European Road Transport Network. In Computational Logistics. 9335. $6^{\text {th }}$ International Conference, ICCL 2015, Delft, The Netherlands, September 23-25, 2015. 617-626.

34 Andrea Conca - Chiara Ridella - Enrico Sapori: A risk assessment for road transportation of dangerous goods: a routing solution. Transportation Research Procedia, 14. (2016), 2890-2899. 
tanulmányozásához, figyelembe véve a biztonságot. A veszélyes árukkal érintett közúti balesetek elemzésének új megközelítése a veszélyes anyagok szivárgásához vezető okra összpontosít. Tanulmányukban bemutatták a közúti fuvarozók minimális költségű útválasztási problémájának korszerüsítését, figyelembe véve a veszélyes árukkal kapcsolatos kockázatokat is. Annak leírása után, hogy a veszélyes áruk szállításának kockázatát hogyan lehet kiszámítani egy útvonalválasztási problémában, a cikk megoldást ír le, amelynek célja egy tervezési és müködtetési döntéshozatali eszköz biztosítása. A cél az volt, hogy a veszélyes árukat szállító fuvarozó az egyes szállítmányok, fuvarok költségein felül kiszámíthassa az egyes utakra vonatkozó további kockázatokat is.

\section{Következtetések}

A veszélyes áruk szállításával kapcsolatos balesetek jelentős kockázatot jelentenek az emberre, a környezetre és a gazdaságra nézve. A közelmúltban már bevezetett technológiák, például a földrajzi információs rendszerek (GIS), a globális múholdas navigációs rendszerek (GPS), az általános csomagkapcsolt rádiószolgáltatás (GPRS), a rádiófrekvenciás azonosítás (RFID) fejlesztése lehetővé teszi a helyzet javítását a lokalizációval és a járművek helyzetének figyelemmel kísérésével, a veszélyes áru állapotával, a jármű helyzetének balesetben történő pontos meghatározása és a kárfelszámolásban érintett beavatkozó erők, a tűzoltóság haladéktalan tájékoztatása a káresetről. Maguk a kárhelyszíni beavatkozásban részt vevő erők és a balesetek megelőzésében, a terület felügyeletében érintett állami, hatósági szervek szervezése által szintén tehetők lépések a biztonság irányában. A térinformatika eszközei lehetővé teszik a veszélyes árukból származó anyagok terjedésének vagy szivárgásának, a lehetséges következményeinek modellezését, és így meghatározhatják a szennyezett terület mértékét a kárfelszámoláshoz szükséges erőforrásokat, hogy minimalizálják a baleset következményeit a legmegfelelőbb módon.

A cikkben bemutatottak szerint számos kockázatértékelési rendszert, modellt, módszertant, megközelítést fejlesztettek már ki a veszélyes áruk szállításikockázat-csökkentési lehetőségeinek azonosítására, amelyeket már sikeresen alkalmaztak az egyes nemzeti kockázatelemzési rendszerekben. Számos rendszer létezik a jármúveket szállító veszélyes áruk ellenőrzésére és a veszélyes áruk szállításának lehető legjobb, legbiztonságosabb útvonalának megtervezésére, elkerülve az emberre és a környezetre jelentett kockázatot.

Az egyes országoktól is függ, hogyan alakítják ki saját kockázatértékelési, nyomonkövetési és útvonaltervezési rendszerüket a veszélyes áruk szállítására, vagy átveszik a már kialakított és a gyakorlatban ellenörzött rendszerek egyikét. Ez a kérdéskör azonban nemcsak egy ország problémája, hanem nemzetközi szinten is megoldandó. Az elmúlt években számos tevékenységet végeztek ezen a területen európai szinten is, de továbbra is megoldást kell találni arra, hogyan lehetne tovább javítani a jelenlegi helyzetet a veszélyes áruk szállításával kapcsolatosan Európában, mivel ez még mindig nincs a megfelelő szintű és egységes ellenőrzés alatt. További feladat a jelen korszak lehetőségeinek megfelelően a lehető leggyorsabb és leghatékonyabb kárfelszámolási lehetőségek megtalálása és biztosítása. 


\section{Felhasznált irodalom}

Adamec, Vladimír - Barbora Schullerova - Adam Vojtěch: Issues of Hazardous Materials Transport and Possibilities of Safety Measures in the Concept of Smart Cities. In Smart City $360^{\circ}$. First EAl International Summit, Smart City $360^{\circ}$, Bratislava, Slovakia and Toronto, Canada, 2016. 790-799. Online: https://doi.org/10.1007/978-3-319-33681-7_70

Majlingova, Andrea - Pántya Péter: Management of risks associated with dangerous goods transportation - review. Védelem Tudomány: Katasztrófavédelmi Online Tudományos Folyóirat, 4. (2019), ksz. 220-246. Online: http://vedelemtudomany.hu/articles/10-majlingova-pantya.pdf

Caliendo, Ciro - Maria Luisa De Guglielmo: Quantitative Risk Analysis on the Transport of Dangerous Goods Through a Bi-Directional Road Tunnel. Risk Analysis, 37. (2017), 1. 116-129. Online: https:// doi.org/10.1111/risa.12594

Caro-Vela, Maria D. - Eugenio M. Fedriani - Ángel F.Tenorio: Design of an Efficient Algorithm to Determine a Near-Optimal Location of Parking Areas for Dangerous Goods in the European Road Transport Network. In Computational Logistics. 9335. $6^{\text {th }}$ International Conference, ICCL 2015, Delft, The Netherlands, September 23-25, 2015. 617-626. Online: https://doi.org/10.1007/9783-319-24264-4_42

Conca, Andrea - Chiara Ridella - Enrico Sapori: A risk assessment for road transportation of dangerous goods: a routing solution. Transportation Research Procedia, 14. (2016), 2890-2899. Online: https://doi.org/10.1016/j.trpro.2016.05.407

Di Fazio, A. - D Bettinelli - E. Louette - J. P. Mechin - M. Zazza - P. Vecchiarelli - L. Domanico: European pathways to introduce EGNOS and Galileo for dangerous goods transport. Transportation Research Procedia, 14. (2016), 1482-1491. Online: https://doi.org/10.1016/j.trpro.2016.05.222

Forigua, Julio - Liliana Lyons: Safety analysis of transportation chain for dangerous goods: A case study in Colombia. Transportation Research Procedia, 12. (2016), 842-850. Online: https://doi. org/10.1016/j.trpro.2016.02.037

Gabryelewicz, I. - P Krupa - J. Sadlowska-Wrzesinska: Online measurement of work safety culture statement of research. In $4^{\text {th }}$ International Conference On Computing And Solutions In Manufacturing Engineering 2016 (COSME'16), Vol. 94. 2017. Online: https://doi.org/10.1051/matecconf/ 20179406008

Janno, Jelizaveta - Ott Koppel: Human factor as the main operational risk in dangerous goods transportation chain. Proceedings of $17^{\text {th }}$ International Scientific Conference Business Logistics in Modern Management. Osijek, Croatia Oct 12-13. 2017. 63-78.

Janno, Jelizaveta - Ott Koppel: Operational risks in dangerous goods transportation chain on roads. Logforum, 14. (2018), 1. 33-41. Online: https://doi.org/10.17270/J.LOG.2018.261

Kanj, H. - J.-M. Flaus: An Agent-based framework for mitigating hazardous materials transport risk. IEEE Conference on Evolving and Adaptive Intelligence Systems. Dec 01-03, France, 2015. Online: https://doi.org/10.1109/EAIS.2015.7368791

Karim, Lamia - Azedine Boulmakoul - Aziz Mabrouk - Ahmed Lbath: Deploying Real Time Big Data Analytics in Cloud Ecosystem for Hazmat Stochastic Risk Trajectories. Procedia Computer Science, 109. (2017), 180-187. Online: htps://doi.org/10.1016/j.procs.2017.05.322

Kátai-Urbán Lajos - Vass Gyula: Veszélyes üzemek és szállítmányok biztonsága Magyarországon, Védelem Tudomány: Katasztrófavédelmi Online Tudományos Folyóirat, 4. (2019), 1. 45-82. Online: http://vedelemtudomany.hu/articles/03-katai-vass.pdf

Kinzhikeyev, Sergey- Agoston Restas: Drone Applications for Supporting Disaster Management. In Karakoc Hikmet - Jozsef, Rohacs - Turan Onder - Sogut M. Ziya: Abstract Book of International Symposium on Sustainable Aviation 2019 (ISSA-2019). 2019. 29. Online: https://doi.org/10.4236/ wjet.2015.33C047

Krejci, L. - B. Schullerova - V. Adamec: Risk Assessment of the Transport of Ammonia and Chlorine in Urban Areas. Chemicke Listy, 112. (2018), 4. 232-236. 
Landucci, Gabriele - Giacomo Antonioni - Alessandro Tugnoli Sarah Bonvicini - Menso Molag - Valerio Cozzani: HazMat transportation risk assessment: A revisitation in the perspective of the Viareggio LPG accident. Journal of Loss Prevention in the Process Industries, 49. (2017), 36-46. Online: https:// doi.org/10.1016/j.jp.2016.08.009

Li, He-Hua - Yu-Jie Wang: Research on the Road Transport Risk of Domestic Hazardous Chemicals. AEBMR - Advances in Economics Business and Management Research, 50. (2017), 164-171. Online: https://doi.org/10.2991/mse-17.2017.42

Li, Weiwei - Jingyan Gu: Application of IC Card License for Road Transportation in Commercial Vehicles Supervision and Service. MATEC Web of Conferences, 81. (2016), 03001. Online: https://doi. org/10.1051/matecconf/20168103001

Łukasik, Zbigniew - Aldona Kuśmińska-Fijałkowska - Jacek Kozyra: Transport of dangerous goods by road from a European aspect. Scientific Journal of Silesian University of Technology. Series Transport, 95. (2017), 109-119. Online: https://doi.org/10.20858/sjsutst.2017.95.11

Malekian, Reza - A. F. Kavishe - B. T. Maharaj - P. K. Gupta - G. Singh - H. Waschefort: Smart Vehicle Navigation System Using Hidden Markov Model and RFID Technology. Wireless Personal Communications, 90. (2016), 4. 1717-1742. Online: https://doi.org/10.1007/s11277-016-3419-1

Nowacki, G. - C. Krysiuk - R. Kopczewski: Dangerous Goods Transport Problems in the European Union and Poland. Transnav-International Journal on Marine Navigation and Safety of Sea Transportation, 10. (2016), 1. 143-150. Online: https://doi.org/10.12716/1001.10.01.16

Rada, Elena Cristina - Navarro Ferronato - Vincenzo Torretta: Individual risk evaluation and interventions for mitigation in the transportation of hazardous goods: a case study. MATEC Web of Conferences, 121. (2017), 06008. Online: https://doi.org/10.1051/matecconf/201712106008

Rázga, Martin - Peter Danišovič - Pavel Poledňák: Extension of risk analysis model for road tunnels. Procedia Engineering, 111. (2015), 687-693. Online: https://doi.org/10.1016/j.proeng.2015.07.133

Rázga, Martin - E. Jančaříková - Peter Danišovič: Research of selected factors of safety in road tunnels for practice. $2^{\text {nd }}$ International Conference on Engineering Sciences and Technologies (ESaT). Slovakia, Jun 29-Jul 01. 2017. Online: https://doi.org/10.1201/9781315393827

Smal, T. - M. Kopczewski: Transportation of Dangerous Goods - Legal and Technical Conditions and Marking of Vehicles. Proceedings of the $20^{\text {th }}$ International Scientific Conference Transport Means 2016. Juodkrante, Lithuania, Oct 05-07, 2016. 191-196.

Zwęgliński, Tomasz: The Use of Drones in Disaster Aerial Needs Reconnaissance and Damage Assessment - Three-Dimensional Modeling and Orthophoto Map Study. Sustainability, 12. (2020), 15. 6080. Online: https://doi.org/10.3390/su12156080

Xie, Yaoyao - Miao Yu - Jie Fu - Dong Chen - Chengyun Yang: A Hazmat Transportation Monitoring System Based on Global Positioning System/ BeiDou Navigation Satellite System and RS485 bus. Proceedings of the $9^{\text {th }}$ International Congress on Image and Signal Processing, BioMedical Engineering and Informatics (CISP-BMEI). Datong, Peoples R China, Oct 15-17, 2016. 1059-1063. Online: https://doi.org/10.1109/CISP-BMEl.2016.7852870

Ye, Ning - Zhong qin Wang - Reza Malekian - Ru chuan Wang - Ting ting Zhao - Darius Andriukaitis - Algimantas Valinevicius - Dangirutis Navikas - Vytautas Markevicius: A hidden Markov model combined with RFID-based sensors for accurate vehicle route prediction. International Journal of Ad Hoc and Ubiquitous Computing, 23. (2016), 1-2. 124-133. Online: https://doi.org/10.1504/ IJAHUC.2016.078473 